\title{
Evaluation of Quality Costs in the Production Organization
}

\author{
Miroslav Prístavka ${ }^{1}$, Koloman Krištof ${ }^{2}$ \\ ${ }^{1}$ Slovak University of Agriculture in Nitra, Faculty of Engineering, Department of Quality and Engineering Technologies, \\ Tr. A. Hlinku 2, 94976 NITRA, Slovakia, miroslav.pristavka@uniag.sk \\ ${ }^{2}$ Slovak University of Agriculture in Nitra, Faculty of Engineering, Department of Machines and Production Biosystems, \\ Tr. A. Hlinku 2, 94976 NITRA, Slovakia, koloman.kristof@uniag.sk
}

\begin{abstract}
Within the context and term of quality it can be comprehended as a subjective character. Every individual has its own requirements, expectations or standards on specific product or service. Thus, these parameters are then connected and defined by different priorities. Many of the customers are willing to pay more money for increased quality of bought product however many of them are forced to decrease their requirements due to the costs and they have to be satisfied by products with lower quality or lesser amount of defined parameters. The main aim of the paper is to observe and analysis of cost system and its effect on product quality through the monitoring, analysis and evaluation of production costs in selected organization. Due to the comprehensive evaluation of the effects of investments on the resulting quality in selected organization a various methods was employed. Among used methods was comparison of investments into production quality by data analysis according to PAF model, mathematics and statistical parameters and Pareto's analysis. There were suggested individual steps by utilization which allows determining, evaluating and creating an individual system of observation and evaluation. Such a system of costs analysis is then suitable for selected companybut not limited to it. The utilization of such a system is therefore applicable at any company or organization which is focused on custom small-series production.
\end{abstract}

Keywords: quality, quality control, costs on quality, PAF model, Pareto's analysis

\section{Introduction}

As competition for world markets becomes more intense and as greater demands are placed on human and natural resources, manufacturers face a formidable challenge - to produce cost competitive products of the highest possible quality (Prior, 1985). Mass customization enhances profitability through a synergy of increasing customer perceived value and reducing the costs of production and logistics. It inherently makes high value-added products and services possible through premium profits derived from customized products (Jiao et al., 2003). Within this context and with closer look to the term of quality it can be comprehended as a subjective character. As it was suggested by Chan (2003) a multi-attribute decision-making technique, an analytic hierarchy process (AHP) can be used to make decisions based on the priority of performance measures. The logistics manager must make judgements as to the organization performance relative to the competition. However, there are different kinds of performance measurement, which have already been discussed in many other studies (Beamon, 1999). Every individual has its own requirements, expectations or standards on specific product or service. Thus, these parameters are then connected and defined by different priorities. Many of the customers are willing to pay more money for increased quality of bought product however many of them are forced to decrease their requirements due to the costs and they have to be satisfied by products with lower quality or lesser amount of defined parameters (Korenko and Kaplík, 2011). In addition, Ramezani et al. (2013) stated that logistic network design has an important and strategic platform in an efficient and effective supply chain management, and usually involves multiple and conflicting goals, such as cost/profit, resource balance, customer responsiveness, quality, and the like. Besides, due to the implementation of government legislation, environmental concern, social responsibility and customer awareness, companies have been forced by customers not only to supply environmentally amicable products but also to be responsible for the returned products. Moreover, the set of Pareto's optimal solutions is obtained and also financial risk relevant to them is computed in order to show the tradeoff between objectives (Ramezani et al., 2013). In general it can be concluded that the term of quality can be imagined individually as a product which will not be faulty, without failures and will fulfil perfectly desired functionality for which it was bought by customer (Kangalov, 2013; Výžinkár et al., 2017). A study of Lai et al. (2005) explores the link between relationship stability and supplier commitment to quality, and the contingency of the link on characteristics of transactions within the framework of transaction cost analysis. It was suggested that supplier firms regard a stable relationship as being positively linked to their commitment to quality for the focal buyer firm. It was also found that the link is stronger when the suppliers' perceptions of a certainty of supply with the buyer firm are greater, while asset specificity and transaction frequency have no impact on the link (Lai et al., 2005). Currently it is almost matter of course that the organizations strive for obtaining certification within the frame of quality management system according to international standards. Due to the growing interest of production organizations to be certified in terms of quality management system the observation of cost monitoring system and its effect on production is among the most valuable parameters in the frame of connected studies (Stasiak-Betlejewska and Borkowski, 2009). Moreover, Mentzer et al. (2004) concluded that logistics services 
have become a significant source of competitive differentiation between firms; significant challenges exist relative to developing logistics service offerings for global business customers. Diverse regulations across borders, longer lead times, and increased transportation costs all add to the difficulty of managing logistics services internationally. As a service offering, logistics is often characterized by intensive customer contact, extensive customization requirements, and a reliance on extrinsic cues for service performance. Because of these qualities, logistics services are also subject to cultural influences that exist in cross-border trade. It was concluded that by identifying specific customer segments, some which may transcend national borders, logistics managers can benefit from reduced costs, enhanced revenue, and the ability to differentiate their offering from the highly competitive marketplace (Metzer et al., 2004).

The main aim of the paper is to observe and analysis of cost system and its effect on product quality through the monitoring, analysis and evaluation of production costs in selected organization. By the evaluation of the results it will identified and concluded the individual cost elements spent by organization TERMOPLAST Inc. (Sered', Slovakia) to ensure the quality of production.

\section{Material and methods}

Due to the comprehensive evaluation of the effects of investments on the resulting quality in selected organization a various methods was employed. The study was conducted on the basis of the organization's management requirements to increase the quality of production parameters. Methods of assessment and processing of the study were selected on the basis of consultations with the management of the organization, the authors of the study, and taking into account scientific knowledge in the field of study. Among used methods was comparison of investments into production quality by data analysis according to PAF model, mathematics and statistical parameters and Pareto's analysis (Obertáš, 2015; Prístavka and Beloev, 2015). All of the used methods are described in more details in following sub-chapters.

\subsection{Comparison of investments}

Comparison of investments into quality improvement is a simple method which was employed after evaluation and processing of individual data sets and following results analysis (Korenko et al., 2015a; Korenko et al., $2015 b$ ). As a compared variables was used the investment into quality in 2015 when the organization do not utilize any system (program) for evaluation and categorisation of such information. Obtained and processed investments from 2015 were then compared with investments recorded in 2016 after incorporation of evaluative and categorisation system. Utilization of employed and defined methods allows accurent observation and monitoring of specific production processes, costs, and in particular, interaction with feedback from the company customers as a main driven criterion of employed quality controle.

\subsection{Data processing}

To achieve main objectives it was used identification and categorisation of investments into production quality according to PAF model which divide these investments into the four main categories: (i) costs on internal loses, (ii) costs on external loses, (iii) costs on evaluation and (iv) costs on prevention. Selected statistical methods of evaluation were separately introduced into the organizations production processes. At the same time, however, all steps were consulted with the company management. This procedure was chosen to ensure the consistency of the assessment methods and their application in the production process in connection with the parallel introduction of the quality management system based at standard ISO 9001.

The specific cost elements and its respective money amounts was then processed and compared as tables by single evaluation in Microsoft EXCEL. The results of comparison are displayed in graphical form as charts.

\subsection{Mathematical and statistical parameters}

Calculation of total costs on production quality was then performed according to following equation:

$$
N_{Q}=N_{I}+N_{E}+N_{H}+N_{P}
$$

Where: $N_{Q}$ - total costs on quality for observed period, $€ ; N_{I}-$ costs on internal loses, $€ ; N_{E}$ - costs on external loses, $€ ; N_{H}-$ costs on evaluation, $€ ; N_{P}-$ costs on prevention, $€$.

After obtaining the result of total costs on quality $\left(N_{Q}\right)$, a share percentage $\left(P_{N Q}\right)$ of total costs in organisation $(N)$ can be calculated by following equation:

$$
P_{N Q}=\frac{N_{Q}}{N} * 100
$$

Since we were able to calculate the whole sum of total costs on quality $\left(N_{Q}\right)$ it is possible to determine by utilization of following equation some of the proportional indicators which results into share percentage of cost groups $\left(N_{I}, N_{E}, N_{H}\right.$ and $\left.N_{P}\right)$ in conjunction with total costs on quality $\left(N_{Q}\right)$ as it is indicated by following equations:

$$
\begin{array}{ll}
K_{1}=\frac{N_{I}}{N_{q}} * 100 & K_{2}=\frac{N_{E}}{N_{q}} * 100 \\
K_{3}=\frac{N_{H}}{N_{q}} * 100 & K_{4}=\frac{N_{P}}{N_{q}} * 100
\end{array}
$$

The proper function of the costs invested into the quality area is essential, from the point of organization, that the costs on prevention $\left(N_{P}\right)$ and costs on evaluation $\left(N_{H}\right)$ are lower in short term in comparison with costs on internal and external loses. It is important condition since the prevention is always better and more advantageous parameter, from the point of long term, as subsequent removal of deficiencies and disorders as was concluded by Prístavka et al. (2014). The share between sums of these two groups in relation with costs on to quality $\left(N_{Q}\right)$ can be calculated according to following equation:

$$
P H_{P}=\frac{N_{P}+N_{H}}{N_{Q}} * 100
$$

The equation for calculation of financial sources share 
invested on to internal and external faults $\left(N_{I}, N_{E}\right)$ in relation to investment on to quality $\left(N_{Q}\right)$ is :

$$
P_{V}=\frac{N_{I}+N_{E}}{N_{Q}} * 100
$$

Therefore, the calculation of costs on quality share $\left(N_{Q}\right)$ in relation to total costs in whole organization $(N)$ is given as following equation:

$$
P_{N}=\frac{N_{Q}}{N} * 100
$$

As last parameters to be calculated is calculation of change index. This index is essential part of evaluation while it provides the overview of dynamics and cost development on quality for a certain period of time (1 year).

$$
I_{N Q}=\frac{N_{Q 1}}{N_{Q 0}}
$$

Where: $N_{Q 1^{-}}$total volume of cost on quality in $1^{\text {st }}$ time period (2016) and $N_{Q 0}$ - total volume of cost on quality in $0^{\text {th }}$ time period (2015).

\subsection{Pareto's analysis}

The procedure for elaboration of Pareto's analysis in selected organization (TERMOPLAST Inc., Sered', Slovakia) consists of a certain steps.

- to define the place of analysis (selection of a specific procedure, activities where the increase of efficiency and organization profit is intended to be adjusted),

- selection of a bold problem,

- selection of a certain time scale of its appearance which allows obtaining a true picture of reality,

- collection of whole data sets which define the problem (it is essential for analysis to obtain the relevant data about functionality and record them into table),

- $\quad$ search for possible causes of the problem, e.g. following Ishikawa's diagram (a diagram of cause - effect) or by the Brainstorming method,

- quantification of faults, e.g. by searched causes,

- plotting of the data in form of column chart. Specifically where the y-axis would represent an individual frequency in $\%$ represented by the height of column and $\mathrm{x}$-axis would represent the causes (the name of causes can be in chart then replaced by symbols with following description in chart legend) sequentially sorted in order of faults appearance and its volume. Subsequently, the order of faults will follow the increase of its appearance, frequency, scale or other criterion. The important is that those must be sorted in descending order - from the greatest to lowest number,

- $\quad$ create on the right side of chart $2^{\text {nd }} y$-axis which will represent the cumulative relative frequency in $\%$ for example,

- plotting of faults data into chart by cumulative curve (the last point in the right side will have a $100 \%$ as $Y$ coordinates),

- document the results of analysis and inform an interested person.

These procedures are adaptable for every specific production process and it should be subsequently applied in analysis process as it is recommended by Korenko et al. (2013) and later on by Hrubec and Cservenáková (2016).

\section{Results and discussion}

\subsection{Brief characteristic of organization}

TERMOPLAST Inc. (Sered', Slovakia) can be described as a small company which main production focus is on processing and production of polymers, thermoplastics specifically. The objective of its business is production and processing of plastic products intended primarily for the customers whom utilise them in horticultural and crop production industries. The type of production is provided in small scale and priority of production is aimed for customized production. The range of plastic products is quite wide since the company producing more than 50 different types of products made from polypropylene (PP), polyvinyl chloride (PVC) - softened and hardened, polyethylene (PE), high density polyethylene (HDPE), low density polyethylene (LDPE) and other types of polymers. Assortment consist mainly of drip irrigation and different accessories for its design, and lawn sprayers (Obertáš, 2015). In selected type of evaluation in this company the focus was paid to identify, apply and evaluate the breakdowns of costs as it is defined by PAF model (Tab. 1).

\subsection{Structure of costs on quality in selected company TERMOPLAST Inc. (Sered', Slovakia)}

\subsection{Costs on quality (year 2015)}


Tab. 1 Overview of invested costs on quality in year 2015

\begin{tabular}{|c|c|c|}
\hline \multicolumn{2}{|c|}{ Year 2015} & \multirow[t]{2}{*}{ Cost, $€$} \\
\hline Code & Group I - Internal loses & \\
\hline NI1 & Costs on prefabrication of products (granulation) & 137.60 \\
\hline NI2 & Costs on processing of input materials due to improper storage & 85.70 \\
\hline NI3 & Costs on machines malfunction removal & 852.90 \\
\hline NI4 & Costs on additional labour in post-processing of plastics & 86.00 \\
\hline NI5 & Costs on waste disposal & 65.00 \\
\hline \multirow[t]{3}{*}{ NI6 } & Costs on various repairs and cleaning of tools & 140.00 \\
\hline & SUM for GROUP I & $1,367.20$ \\
\hline & Group E - External loses & \\
\hline NE1 & Costs on complaints (travel fees, transport fees) & 57.00 \\
\hline NE2 & Costs on the return of poor quality products and their replacement & 185.00 \\
\hline NE3 & Loses from prize lowering (lower quality) & 23.00 \\
\hline \multirow[t]{3}{*}{ NE4 } & Fees for air pollution & 200.00 \\
\hline & SUM for GROUP E & 465.00 \\
\hline & Group $\mathrm{H}-$ Costs on evaluation & \\
\hline NH1 & Purchase of measuring equipment & 53.00 \\
\hline NH2 & Costs on inspection (testing+wages) & 485.50 \\
\hline \multirow[t]{3}{*}{ NH3 } & Costs on machines revision & 170.00 \\
\hline & SUM for GROUP H & 708.50 \\
\hline & GROUP P - Costs on prevention & \\
\hline NP1 & Investments into reduction of accident rate & 350.00 \\
\hline NP2 & Costs on planning and technical preparation of production & 89.00 \\
\hline NP3 & Costs on preparation of documents and company standards regarding to ensure the quality & 123.00 \\
\hline NP4 & Training and education of employees (BOZP and PO) & 70.00 \\
\hline NP5 & Investments into improvement of production quality & 960.00 \\
\hline NP6 & Costs on technical revision of new products & 0.00 \\
\hline \multirow[t]{2}{*}{ NP7 } & Investments on reduction of environmental pollution & 320.00 \\
\hline & SUM for GROUP P & 1912.00 \\
\hline \multicolumn{2}{|c|}{ SUMMARY (NQ) } & 4452.70 \\
\hline
\end{tabular}

\subsection{Evaluation of costs on quality (year 2015)}

Calculation of total costs on quality was performed according to equation (1) described in methodology chapter by sum of costs groups.

$$
N_{Q}=4452.70 \text { Eur }
$$

By utilization of proportional indicators (equations (3)) it is possible to obtain the share of individual costs groups in relation with total costs on quality in selected year 2015. In order to emphasise the differences, share and readability a chart is also provided (Fig. 1).

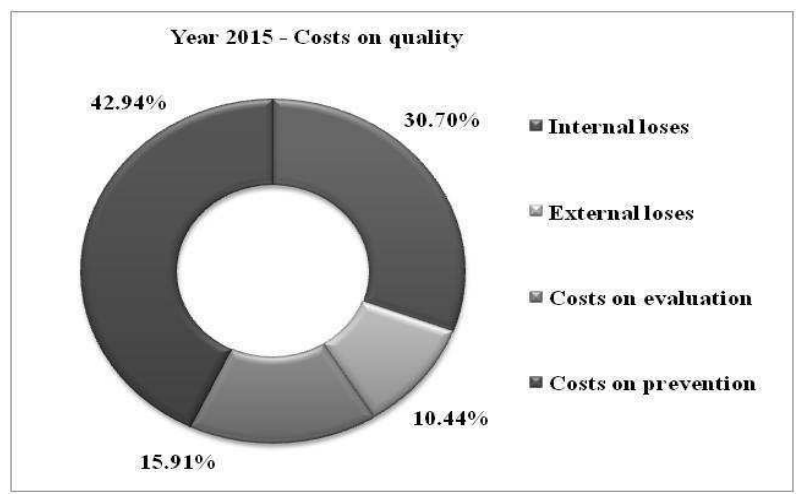

Fig. 1 Share of costs group in relation with total costs on quality

From Fig. 1 and Tab. 1 it is possible to identify that the greatest costs group are consisting of costs on prevention. It can be concluded that company TERMOPLAST
Inc. (Sered', Slovakia) in year 2015 invested almost half of the total investments on quality through a various investments into increase of production quality and prevention of the risks. As a second greatest group are formed by costs on internal loses which in year 2015 represents almost one third of total costs on quality and the greatest share of this third consist of faults removal costs. Yet Porteus (1986) introduce a simple model that captures a significant relationship between quality and lot size. In his research the system incurs an extra cost for rework and related operations for each defective piece that it produces. There we emphasised a three options for investing in quality improvements: (i) reducing the probability that the process moves out of control (which yields fewer defects, larger lot sizes, fewer setups, and larger holding costs); (ii) reducing setup costs (which yields smaller lot sizes, lower holding costs, and fewer defects); and (iii) simultaneously using the two previous options. By assuming a specific form of the investment cost function for each option, it is possible explicitly to obtain the optimal investment strategy (Porteus, 1986).

\subsection{Costs on prevention and evaluation (year 2015)}

It is obvious, that for proper function of company it is beneficial if costs on prevention and evaluation are greater than costs on removal of faults. To ensure the fulfilment of this condition: $N_{H}+N_{P}>N_{I}+N_{E}$ for year 2015 it is possible to confirm by following calculations utilizing equations (4) and (5) and plotting in form of 
charts (Fig. 2).

$$
\mathrm{PH}_{P}=58.85 \%
$$

Share of costs on prevention and evaluation in relation with total costs in year 2015 was $58.85 \%$.

$$
P_{V}=41.15 \%
$$

Share of costs on faults removal in relation with total costs was $41.15 \%$.

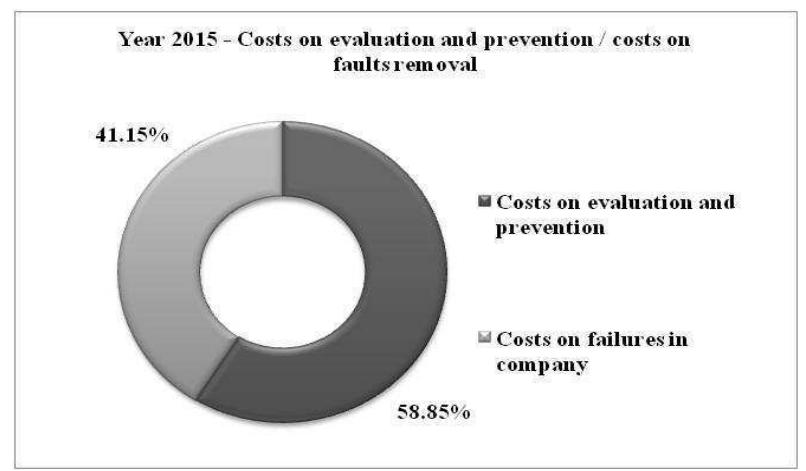

Fig. 2 Share of costs on evaluation and prevention in relation with costs on faults removal for condition $\mathrm{N}_{H}+$

$$
N_{P}>N_{I}+N_{E}
$$

Share of costs on evaluation and prevention at level $58.85 \%$ can be considered as a positive phenomenon in the field of improvement and control of production quality. Moreover, Singels et al. (2001) conducted a study which aims to find out if ISO certification indeed results in better performance outcomes for organizations. It was concluded that this is of importance, for example, for those organizations that seek ISO certification in order to improve their performances. In order to continue in our later calculations and indicators determination it is important to obtain the knowledge about the economical situation in company, e,g. to know: total sales, total costs on faults removal in company and other economic parameters given in Tab. 2 .

Tab. 2 Total sales and costs on faults removal in year 2015

\begin{tabular}{|ll|}
\hline Year 2015 & $(€)$ \\
\hline Total sales & 131,122 \\
Total costs in company & 135,344 \\
\hline Loss & 4,222 \\
\hline \\
\hline \\
\end{tabular}

Fig. 3 Share of costs on quality in relation with total costs in company

\begin{tabular}{|c|c|c|}
\hline \multicolumn{2}{|c|}{ Year 2016} & \multirow[t]{2}{*}{ Costs, $\epsilon$} \\
\hline Code & Group I - Internal loses & \\
\hline NI1 & Costs on prevention and prefabrication of products (granulation) & 120.50 \\
\hline NI2 & Costs on processing of input materials due to improper storage & 99.30 \\
\hline NI3 & Costs on machines malfunction removal & $1,205.00$ \\
\hline NI4 & Costs on additional labour in post-processing of plastics & 73.00 \\
\hline NI5 & Costs on waste disposal & 71.00 \\
\hline \multirow[t]{3}{*}{ NI6 } & Costs on various repairs and cleaning of tools & 105.00 \\
\hline & SUM for GROUP I & $1,673.80$ \\
\hline & Group E - External loses & \\
\hline NE1 & Costs on complaints (travel fees, transport fees) & 66.00 \\
\hline NE2 & Costs on the return of poor quality products and their replacement & 143.00 \\
\hline NE3 & Loses from prize lowering (lower quality) & 20.00 \\
\hline \multirow[t]{3}{*}{ NE4 } & Fees for air pollution & 132.00 \\
\hline & SUM for GROUP E & 361.00 \\
\hline & Group $\mathrm{H}$ - Costs on evaluation & \\
\hline NH1 & Purchase of measuring equipment & 00.00 \\
\hline NH2 & Costs on inspection (testing + wages) & 430.00 \\
\hline \multirow[t]{3}{*}{ NH3 } & Costs on machines revision & 170.00 \\
\hline & SUM for GROUP H & 600.00 \\
\hline & Group P - Costs on prevention & \\
\hline NP1 & Investments into reduction of accident rate & 130.00 \\
\hline NP2 & Costs on planning and technical preparation of production & 415.00 \\
\hline NP3 & Costs on preparation of documents and company standards regarding to ensure the quality & 102.00 \\
\hline NP4 & Training and education of employees (BOZP and PO) & 70.00 \\
\hline NP5 & Investments into improvement of production quality & 310.00 \\
\hline NP6 & Costs on technical revision of new products & 250.00 \\
\hline \multirow[t]{2}{*}{ NP7 } & Investments on reduction of environmental pollution & 00.00 \\
\hline & SUM for GROUP P & $1,277.00$ \\
\hline \multicolumn{2}{|c|}{ SUMMARY (NQ) } & $3,991.80$ \\
\hline
\end{tabular}

3.6 Costs on quality (year 2016)

Tab. 3 Overview of invested costs on quality in year 2016 
In order to obtain the share of costs on quality in relation with total costs of whole organization it is necessary to obtain the knowledge of total costs which was recorded in year 2015. The sum $(N)$ then represents value 135,344 $€$. Share of costs on quality in relation with total costs can be then calculated according to equation (6) in form of charts given in Fig. 3.

$$
P_{N}=3.29 \%
$$

\subsection{Evaluation of costs on quality (year 2016)}

Calculation of total costs on quality was performed according to equation (1) described in methodology chapter by sum of costs groups.

$$
N_{Q}=3,911.80 \text { Eur }
$$

By utilization of proportional indicators (equations (3)) it is possible to obtain the share of individual costs groups in relation with total costs on quality in selected year 2016. In order to emphasise the differences, share and readability a chart is also provided (Fig. 4).

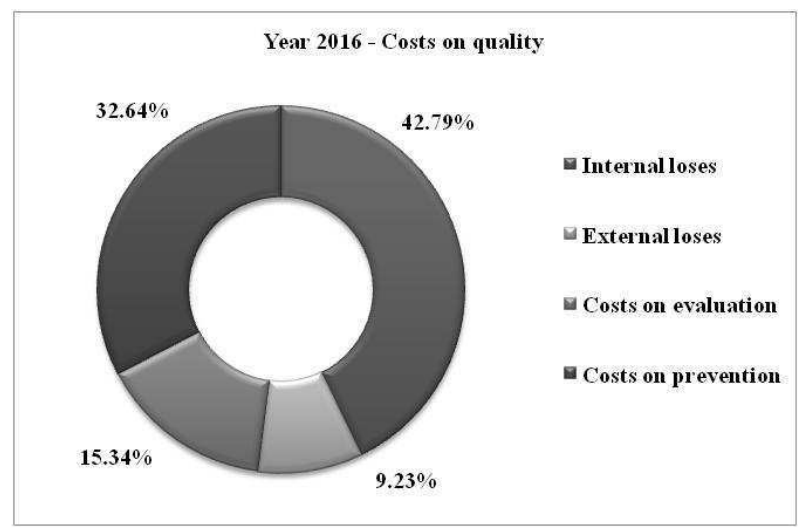

Fig. 4 Share of costs group in relation with total costs on quality

From Fig. 4 and Tab. 3 it is possible to identify a significant difference in costs on quality while comparing year 2015 and 2016. In year 2016 the greatest group of costs consist of costs on internal faults and mainly due to removal of failures. Subsequently, costs on prevention represents the second greatest part of costs where the main part consisting of costs on planning and technical preparation of production and following investments on quality of production. In these instances also Chan et al. (2005) suggested that customers focus on product quality, product delivery time and cost of product. Because of these, a company should introduce a quality system to improve and increase both quality and productivity continuously. It was concluded that total productive maintenance (TPM) is a methodology that aims to increase the availability of existing equipment hence reducing the need for further capital investment (Podprocká et al., 2016).

\subsection{Costs on prevention and evaluation (year 2016)}

It obvious, that for proper function of company it is beneficial if costs on prevention and evaluation are greater than costs on removal of faults. To ensure the fulfilment of this condition: $N_{H}+N_{P}>N_{I}+N_{E}$ for year 2016 it is possible to confirm by following calculations utilizing equations (4) and (5) and plotting in form of charts (Fig 5).

$$
\mathrm{PH}_{P}=47.98 \%
$$

Share of costs on prevention and evaluation in relation with total costs in year 2016 was $47.98 \%$.

$$
P_{V}=52.02 \%
$$

Share of costs on faults removal in relation with total costs was $52.02 \%$.

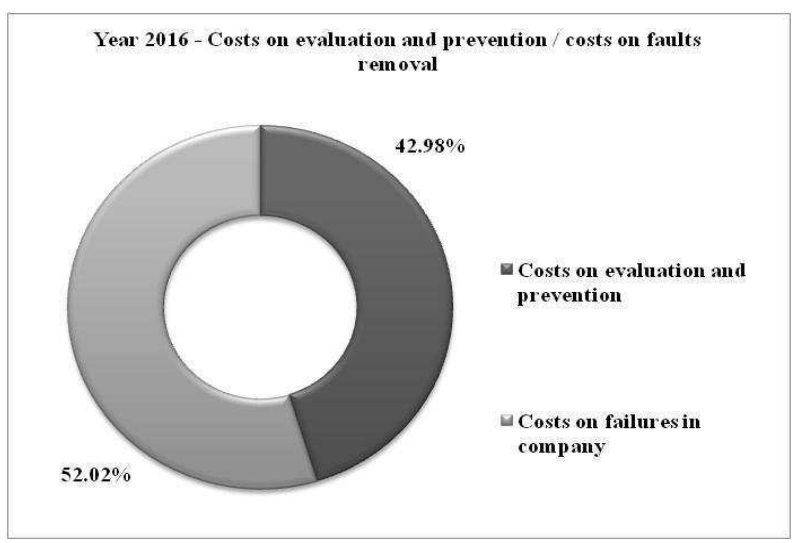

Fig. 5 Share of costs on evaluation and prevention in relation with costs on faults removal for condition $N_{H}+$

$$
N_{P}>N_{I}+N_{E} \text {. }
$$

As it is obvious from Fig. 5 the costs on failures in year 2016 were greater in comparison with costs on prevention and evaluation. This increase was caused mainly by the increase of machine failures which results in increasing costs needed for its removal. This conclusion leads to an importance of increase maintenances of machines and following prevention which may therefore lead to avoiding of such a situations in the future. However, Thatcher and Oliver (2001) concluded that it is commonly assumed that such investments should lead to gains in both profits and productivity. However, using a closed-form analytical model we challenge this underlying assumption and demonstrate that investments in certain efficiency-enhancing technologies may be expected to decrease the productivity of profit-maximizing firms.

Tab. 5 Total sales, total costs and profit in year 2016

\begin{tabular}{ll}
\hline Year 2016 & $\boldsymbol{\epsilon}$ \\
\hline Sales & 101,612 \\
Total costs in company & $99,579.8$ \\
\hline Difference/profit & $2,032.2$ \\
\hline \multicolumn{1}{|c|}{ Year 2016 - Share of costs on quality NQ/ total costs N } \\
\\
\end{tabular}

Fig. 6 Share of costs on quality in relation with total costs in company 
Share of the costs on quality in relation with total costs in company will be then calculated following equation (6) and presented in form of chart (Fig. 6).

$$
P_{N}=3.93 \%
$$

The cost change index represents the dynamics of the cost of quality development between the reference periods 2015 and 2016 and it can be calculated by utilizing equation (7).

$$
I_{N Q}=0.88
$$

Therefore, costs on quality in year 2016 decrease in comparison with year 2015 about $12.15 \%$. However, Khan et al. (2011) amalgamate this phenomenon in their review study. It was stated that the study of a supply chain would remain incomplete until the researchers consider a number of practical scenarios. These scenarios can be, but are not limited to: imperfect items from suppliers, imperfect items in a production stage, transfer of knowledge from cycle to cycle and different strategies of dispatch of products to the buyers. Future research could also concentrate on examining the effect that quality improvement has on future demand rates which could be stochastic (Khan et al., 2011).

\subsection{Evaluation of the costs according to Pareto's ana- lysis}

3.10 Pareto's analysis of costs (year 2015)

\begin{tabular}{|c|c|c|c|c|}
\hline No. & Cost item name & Cost, $€$ & Share, $\%$ & $\begin{array}{l}\text { Cumulative frequ- } \\
\text { ency, } \%\end{array}$ \\
\hline 1 & Investments into quality & 960.00 & 21.56 & 21.56 \\
\hline 2 & Costs on failures removal & 852.90 & 19.15 & 40.71 \\
\hline 3 & Costs on control and testing & 485.50 & 10.90 & 51.61 \\
\hline 4 & Investments to reduction of accident rate & 350.00 & 7.86 & 59.47 \\
\hline 5 & Investments on reduction of environmental pollution & 320.00 & 7.19 & 66.66 \\
\hline 6 & Fees for air pollution & 200.00 & 4.49 & 71.15 \\
\hline 7 & $\begin{array}{l}\text { Costs on the return of poor quality products and their replace- } \\
\text { ment }\end{array}$ & 185.00 & 4.15 & 75.30 \\
\hline 8 & Costs on machines revision & 170.00 & 3.82 & 79.12 \\
\hline 9 & Costs on various repairs and cleaning of tools & 140.00 & 3.14 & 82.26 \\
\hline 10 & $\begin{array}{l}\text { Costs on prevention and prefabrication of products (granula- } \\
\text { tion) }\end{array}$ & 137.60 & 3.09 & 85.35 \\
\hline 11 & $\begin{array}{l}\text { Costs on preparation of documents and company standards re- } \\
\text { garding to ensure the quality }\end{array}$ & 123.00 & 2.76 & 88.11 \\
\hline 12 & Costs on technical preparation of production & 89.00 & 2.00 & 90.11 \\
\hline 13 & Costs on additional labour in post-processing of plastics & 86.00 & 1.93 & 92.04 \\
\hline 14 & Costs on processing of input materials due to improper storage & 85.70 & 1.92 & 93.96 \\
\hline 15 & Training and education of employees (BOZP and PO) & 70.00 & 1.57 & 95.53 \\
\hline 16 & Costs on waste disposal & 65.00 & 1.46 & 96.99 \\
\hline 17 & Costs on complaints (travel fees, transport fees) & 57.00 & 1.28 & 98.27 \\
\hline 18 & Purchase of measuring equipment & 53.00 & 1.19 & 99.46 \\
\hline 19 & Loses from prize lowering (lower quality) & 23.00 & 0.52 & 99.98 \\
\hline 20 & Costs on technical revision of new products & 00.00 & 0.00 & 99.98 \\
\hline
\end{tabular}

Tab. 6 Costs on quality according to Pareto's analysis in year 2015

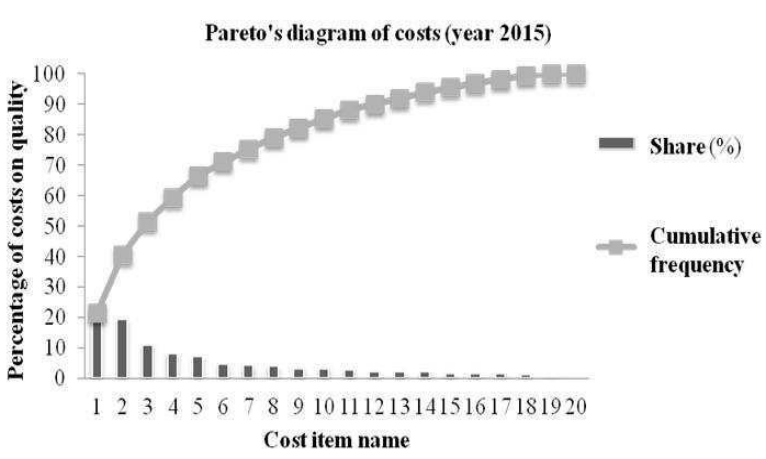

Fig. 7 Pareto's analyses of costs in year 2015
Level between significant and lower significant costs is commonly changing criterion (Davies, 2001) however it is mostly considered to be at $50 \%$. Therefore, based on the results recorded in Tab. 6 and Fig. 7 it can be concluded that the greatest portion of costs on quality in year 2015 were spent by company through investments into improvement of quality production. As a second greatest proportion of costs on the quality was observed through financial spends on machine repairs. At third place were then observed costs on control and testing prefabricated products and newly produced items where the final properties needs to be double checked for inaccuracies and securing the indent quality parameters. The rest of the costs 
did not form so significant portion of internal costs on quality however its importance and space where its emergence cannot be ignored by company for sure. For example, Pet-Edwards (1998) stated that the long-term liability for hazardous waste and the huge expense in cleaning up earlier waste spills and disposal sites require a comprehensive approach on how to manage and reduce wastes.
Approaches include source reduction, in process recycling, and reuse activities. In this context it can be concluded that Total quality management (TQM) provides a powerful framework that can be used to implement a corporation's environmental vision (Pet-Edwards, 1998).

\subsection{Pareto's analysis of costs in year 2016}

Tab. 7 Costs on quality according to Pareto's analysis in year 2016

\begin{tabular}{|c|c|c|c|c|}
\hline No. & Cost item name & Cost, $€$ & $\begin{array}{l}\text { Share, } \\
\text { \% }\end{array}$ & $\begin{array}{l}\text { Cumulative frequ- } \\
\text { ency, } \%\end{array}$ \\
\hline 1 & Costs on failures removal & $\begin{array}{l}1,205 . \\
00\end{array}$ & 30.80 & 30.80 \\
\hline 2 & Costs on control and testing & 430.00 & 10.99 & 41.79 \\
\hline 3 & Costs on planning and technical preparation of production & 415.00 & 10.61 & 52.40 \\
\hline 4 & Investments on improvement of quality & 310.00 & 7.92 & 60.32 \\
\hline 5 & Costs on technical revision of new products & 250.00 & 6.39 & 66.71 \\
\hline 6 & Costs on machines revision & 170.00 & 4.35 & 71.06 \\
\hline 7 & Costs on the return of poor quality products and their replacement & 143.00 & 3.66 & 74.72 \\
\hline 8 & Fees for air pollution & 132.00 & 3.37 & 78.09 \\
\hline 9 & Investments to reduction of accident rate & 130.00 & 3.32 & 81.41 \\
\hline 10 & Costs on prevention and prefabrication of products (granulation) & 120.50 & 3.08 & 84.49 \\
\hline 11 & Costs on various repairs and cleaning of tools & 105.00 & 2.68 & 87.17 \\
\hline 12 & $\begin{array}{l}\text { Costs on preparation of documents and company standards regar- } \\
\text { ding to ensure the quality }\end{array}$ & 102.00 & 2.61 & 89.78 \\
\hline 13 & Costs on processing of input materials due to improper storage & 99.30 & 2.54 & 92.32 \\
\hline 14 & Costs on additional labour in post-processing of plastics & 73.00 & 1.87 & 94.19 \\
\hline 15 & Costs on waste disposal & 71.00 & 1.82 & 96.01 \\
\hline 16 & Training and education of employees (BOZP and PO) & 70.00 & 1.79 & 97.80 \\
\hline 17 & Costs on complaints (travel fees, transport fees) & 66.00 & 1.69 & 99.49 \\
\hline 18 & Loses from prize lowering (lower quality) & 20.00 & 0.51 & 100.00 \\
\hline 19 & Purchase of measuring equipment & 0.00 & 0.00 & 100.00 \\
\hline 20 & Investments on reduction of environmental pollution & 0.00 & 0.00 & 100.00 \\
\hline
\end{tabular}

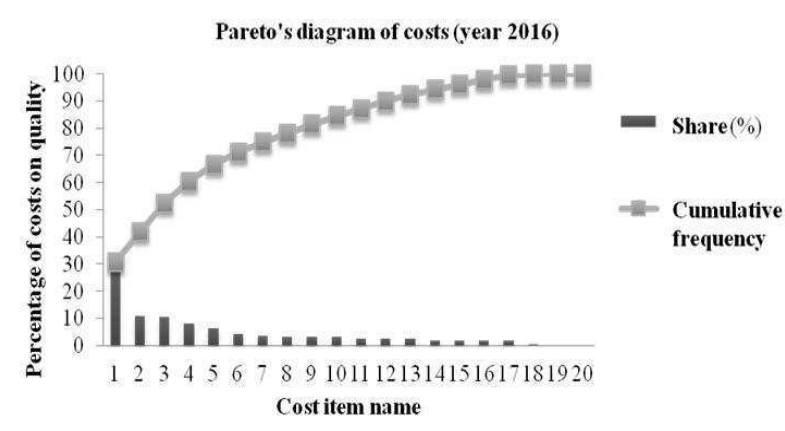

Fig. 8 Pareto's analyses of costs in year 2016

Similarly as in previous part of the study a same level of $50 \%$ was set between significant and less significant cost items. Therefore, as it obvious from Tab. 7 and Fig. 8 it is possible to observe that in year 2016 as a greatest portion of financial resources were invested by the company on failures removal. As another significant investment of resources emerge the costs on control and testing. In relation with introduction of new product into production process are the third greatest costs on planning and technical preparation of production process. Even Ronen and Spector (1992) stated that the Pareto's approach concentrates on the important and costly elements of the organization. Therefore it was developed the model as a top-management decision-support tool that may be applied in areas such as buffer policy, assessment of protective capacity, investment in production resources and identification and priorization of areas for improvement, while the model combines the Pareto's approach with the TOC (the theory of constraints) approach (Ronen and Spector, 1992).

Similarly, as in year 2015, also in the next year of 
evaluation there are financial items among more significant but also among less significant however a constant observation and evaluation and following application of corrective measures will lead in company level to lower almost all of the internal and external cost. Even Mohanty and Dahanayka (1989) stated that there are many ways to upgrade the performance of a production system to ensure that the products manufactured or the services rendered meet quality requirements. This measures will then surely have the positive effect on total economical situation in company as well as it will help company TERMOPLAST Inc. (Sered', Slovakia) to increase the sound of company among the customers environment. However, Mohanty and Dahanayka (1989) suggested that improving quality is a complex job requiring the use of many different types of information. Perhaps the hardest part of improving quality in any process is identifying the cause-and-effect relationships which was later also concluded by Dudas et al. (2014).

The management of the organization has adopted all the proposed methods to quantify the costs on quality that have been deducted through statistical methods and by the convincing of individual workers whole systém was set as stable and working. The organization has committed to maintain the established methods and further reduce individual costs.

However, the natural question arises as to how to continue with SMK certification and certification so that the management system is stable to be homogeneous throughout the organization, has no gaps and shortcomings and that all staff consider it a natural part of their work. A key prerequisite for any SMK organization improvement is the decision-making of the top management to improve the system. However, such a decision may only be taken after considering of the following: (I) analysis of the strengths and weaknesses of the organization operating within the existing SMK, (II) analysis of the existing and potential market, considering possible changes and trends, (III) assessing the meaning of improvement and the related objectives, (IV) considering whether or not to improve existing SMK or whether it corresponds to the current and, in particular, the future situation, and therefore the effort would be unnecessary and (V) familiarizing the entire organization with its goals and intentions and the need for SMK changes.

If all these preparatory stages are successful and top management decides to start improving SMK, they must implement four major measures: (I) update and clarify the vision of the organization as a result of the decision to start with the improvement of SMK, (II) interpret and align ISO quality management principles with a vision, explain to all workers and engage them in their implementation, (III) create and implement an information and communication system that meets the objectives and objectives of the policy of improvement, (IV) schedule the boot phase, during which the current processes and the current SMK are transformed into desirable SMKs. It is natural that these steps are interlinked and that they require unified cooperation.

However, it must be acknowledged that obtaining a SMK certification valid for the whole organization is a time-consuming and economically demanding process, which is not logically justified in any organization with regard to its objectives and activities. It is natural that the "best" proof of the quality of a metrological unit is a SMK certificate according to STN EN ISO 9001: 2016. However, this is an ideal condition, which is financially, organisationally and professionally demanding and therefore difficult to achieve. So what to do? A worldwide and continually increasing emphasis on the need to establish SMK in organizations indicates that non-accredited entities will not have a market place within a short space of time. If an organization wants to prove it depends on customer satisfaction, it has the ability to implement SMK and, in simpler cases, register it. Practically it means that it fulfills the requirements of STN EN ISO 9001: 2016 but only in selected areas.

The integrity of all organization management systems must be the satisfaction of customers who are in particular on a single market with lots of offers and promises. Twenty years of successful SMK implementation according to ISO standards, confirms that this is a successful way, although the gradual acquisition of experience has modified and continues to modify the relevant methods, partial steps, and sometimes the structure of SMK itself.

For organizations where the overwhelming majority operate on a project management basis, the quality management system is of benefit in defining relationships between project implementation and support, such as purchasing, choosing subcontractors, or logistics. If management is really interested in the development of its organization, it should also focus on increasing the level of its employees, improving and consolidating relationships with suppliers and customers should perceive and support its surroundings. To that end, standards such as ISO 9001 become a tool that can be fully utilized. Standards in this case serve the true goal - as a guide to introducing a management system that is common in any country in the world. By maintaining good relationships with our employees, suppliers or neighbors, the company makes it clear that it plans not only for the moment but also for the future. A well-motivated employee, a satisfied supplier and a customer, and the environment are the best prerequisites for the smooth development of the company. The decision to issue depends only on specific managers and owners of companies. However, it should be remembered that the costs incurred will be returned in the form of the satisfaction of all the parties involved and a greater prospect of further procurement (Legát et al., 2017).

\section{Conclusions}

The results of analysis of costs on quality indicated that the greatest financial expenses are spent by company on removal of machine failures. From this reason it could be recommended to perform controls, revisions and cleaning of selected machines at regular intervals. The regular determination of machinery operational state by utilization of the diagnostics and measuring devices should be matter of course. The following controls should be recorded and further compared by using of check lists methodology. This recommendation is even more important since prevention and early diagnostics is less 
costly what is beneficial for whole production process and at the end for company as a whole.

Further it can be recommended to perform visual and metrological revision in more the $25 \%$ of products produced from a single production batch. This process is more time consuming however it will surely lead to less inaccuracies at the basement of producer which then will result in less time and costs consumed on prefabrications of products in lower quality and also lesser rate of complains. In these instances it can be recommended employment and utilization of knowledge of KAIZEN strategy (the way of constant improvement) at whole company level. This methodology, process monitoring and evaluation of costs with following employment of mathematical and statistical analysis for system of evaluation of costs on quality is therefore recommended to be applied in any organization focused on small-scale production. By utilization of such procedures will lead to decrease of further needed investments and simultaneously to increase of efficiency of production processes.

The determination and evaluation of individual costs items is difficult and specific from company to company. From this reason we have suggested individual steps by utilization which allows determining, evaluating and creating an individual system of observation and evaluation. Such a system of costs analysis is then suitable for selected company (TERMOPLAST Inc., Sered', Slovakia) but not limited to it. The utilization of such a system is therefore applicable at any company or organization which is focused on custom small-series production.

\section{Acknowledgement}

The study was supported by projects: KEGA no. 039SPU-4/2017 Innovative teaching subjects, focusing on quality management, metal machining and metrology interact on practical requirements; and VEGA no. 1/0718/17 Study about the effect of technological parameters of the surface coating in agricultural and forestry techniques for qualitative parameters, safety and environmental acceptability.

\section{References}

[1] BEAMON, B.M. (1999). Measuring supply chain performance. In International Journal of Operations and Production Management, vol. 19, no. 3, pp. 275-292.

[2] CHAN, F.T.S. (2003). Performance measurement in a supply chain. In International Journal of Advanced Manufacturing Technology, vol. 21, no. 7, pp. 534-548.

[3] CHAN, F.T.S. - LAU, H.C.W. - IP, R.W.L. CHAN, H.K. - KONG, S. (2005). Implementation of total productive maintenance: A case study. In International Journal of Production Economics, vol. 95 , no. 1, pp. 71-94.

[4] DAVIES, E.C. (2001). The quality gurus. In Manufacturing Engineer, vol. 80, no. 5, pp. 231-236.
[5] DUDAS, C. - NG, A.H.C. - PEHRSSON, L. BOSTRÖM, H. (2014). Integration of data mining and multi-objective optimisation for decision support in production systems development. In International Journal of Computer Integrated Manufacturing, vol. 27, no. 9, pp. 824-839.

[6] HRUBEC, J. - CSERVENÁKOVÁ, J. (2016). Production quality engineering. $1^{\text {st }}$ ed. Nitra : Slovak University of Agriculture in Nitra. $180 \mathrm{pp}$. ISBN 978-80-552-1536-5. (In Slovak: Inžinierstvo kvality produkcie).

[7] JIAO, J. - MA, Q. - TSENG, M.M. (2003). Towards high value-added products and services: Mass customization and beyond. In Technovation, vol. 23 , no. 10 , pp. 809-821.

[8] KANGALOV, P. (2013). Methods and diagnostic tools. Ruse: Angel Kanchev University of Ruse, pp. 49-53 2013. ISBN 978-619-90013-3-2.

[9] KHAN, M. - JABER, M.Y. - GUIFFRIDA, A.L. ZOLFAGHARI, S. (2011). A review of the extensions of a modified EOQ model for imperfect quality items. In International Journal of Production Economics, vol. 132, no. 1, pp. 1-12.

[10] KORENKO, M. - BELOEV, H. - KAPLÍK, P. (2013). Quality control, using PPAP method (Scientific monograph). $1^{\text {st }}$ ed. Ruse: Angel Kanchev University of Ruse, pp. 138. ISBN 978-6197071-12-2.

[11] KORENKO, M. - BUJNA, M. - FÖLDEŠIOVÁ, D. - DOSTÁL, P. - KYSELICA, P. (2015a). Risk analysis at work in manufacturing organization. In Acta Universitatis Agriculturae et Silviculturae Mendelianae Brunensis, vol. 63, no. 5, pp. 14931497.

[12] KORENKO, M. - KAPLÍK, P. (2011). Improvement of process performance and efficiency in a production organisation using a Six Sigma method. In Acta Technologica Agriculturae, vol. 14, no. 4, pp. 105-109.

[13] KORENKO, M. - PRÍSTAVKA, M. DRLIČKA, R., (2015b). Process Quality Management. Manažérstvo kvality procesov. $1^{\text {st }}$ ed. Nitra : Slovak University of Agriculture in Nitra, 144 pp. ISBN 978-80-552-1316-3. (In Slovak: Manažérstvo kvality procesov).

[14] LAI, K. H. - CHENG, T.C.E. - YEUNG, A.C.L. (2005). Relationship stability and supplier commitment to quality. In International Journal of Production Economics, vol. 96, no. 3, pp. 397410.

[15] LEGÁT, V. - ALEŠ, Z. - HLADÍK, T. (2017). Maintenance Audit: the Tool for Maintenance Management Quality of Manufacturing Equipment. In Manufacturing Technology, vol. 17, no. 1, pp. 53-62. 
[16] MENTZER, J.T. - MYERS, M.B. - CHEUNG, M.S. (2004). Global market segmentation for logistics services. In Industrial Marketing $\mathrm{Ma}$ nagement, vol. 33, no. 1, pp. 15-20.

[17] MOHANTY, R.P. - DAHANAYKA, N. (2014). Process improvement: evaluation of methods. In Quality Progress, vol. 22, no. 9, pp. 45-48.

[18] OBERTÁŠ, A. (2015). Monitoring and evaluation of quality costs in the manufacturing organization (Diploma thesis). $1^{\text {st }}$ ed. Nitra: Slovak University of Agriculture in Nitra, pp. 69, 2015. (In Slovak: Sledovanie a vyhodnocovanie nákladov na kvalitu vo výrobnej organizácii).

[19] PET-EDWARDS, J. (1998). Pollution prevention within a total quality management environment: A multiple criteria focus. In International Journal of Industrial Engineering: Theory Applications and Practice, vol. 5, no. 1, pp. 88-98.

[20] PODPROCKÁ, R. - MALIK, J. BOLIBRUCHOVÁ, D. (2016). Influence of the Selected Technological Factors on the Elimination of Misruns. In Manufacturing Technology, vol. 16 , no. 1 , pp. 239-243.

[21] PORTEUS, E. L. (1986). OPTIMAL LOT SIZING, PROCESS QUALITY IMPROVEMENT AND SETUP COST REDUCTION. In Operations Research, vol. 34, no. 1, pp. 137-144.

[22] PRIOR, D. (1985). Quality control information systems .In Quality and Reliability Engineering International, vol. 1, no. 4, pp. 227-234.

[23] PRÍSTAVKA, M. - BELOEV, H. (2015). Engineering of Products Quality. $1^{\text {st }}$ ed. Ruse: Angel Kanchev University of Ruse, 187 pp. ISBN 978954-712-655-8.
[24] PRÍSTAVKA, M. - BELOEV, H. - KROČKO, V. (2014). Quality Control in Production Processes (Scientific monograph). $1^{\text {st }}$ ed. Ruse: Angel Kanchev University of Ruse, 93 pp. ISBN 978-6197071-62-7.

[25] RAMEZANI, M. - BASHIRI, M. TAVAKKOLI-MOGHADDAM, R. (2013). A new multi-objective stochastic model for a forward/reverse logistic network design with responsiveness and quality level. In Applied Mathematical Modelling, vol. 37, no. 1-2, pp. 328-344.

[26] RONEN, B. - SPECTOR, Y. (1992). Managing system constraints: A cost/utilization approach. In International Journal of Production Research, vol. 30, no. 9, pp. 2045-2061.

[27] SINGELS, J. - RUËL, G. - VAN DE WATER, H. (2001). ISO 9000 series certification and performance. In International Journal of Quality and Reliability Management, vol. 18, no. 1, pp. 62-75.

[28] STASIAK-BETLEJEWSKA, R. BORKOWSKI, S. (2009). Controlling w odniesieniu do systemu produkcyjnego. [In:] Cele i uwarunkowania funkcjonowania współczesnych przedsiębiorstw. Red.nauk. Janusz Dworak, Tadeusz Falencikowski. Wyd.Wyż.Szk.Bank. Gdańsk, ISBN: 978-83-61712-12-1, ISSN: 1899-9867.

[29] THATCHER, M.E. - OLIVER, J.R. (2001). The impact of technology investments on a firm's production efficiency, product quality, and productivity. In Journal of Management Information Systems, vol. 18, no. 2, pp. 17-45.

[30] VÝŽINKÁR, M. - GAŠPAROVIČ, D. ŽARNOVSKÝ, J. - KOVÁČ, I. - BERNÁT, R. (2017). Use of Technical Diagnostics Means in Industrial Practice. In Manufacturing Technology, vol. 17, no. 3, pp. 401-407. 